\title{
ON THE LARVAL AND PUPAI. STAGES OF BIBIO JOHANNIS L.
}

By HUBERT M. MORRIS, M.Sc. (Manch.).

(From the Department of Agricultural Entomology, Manchester University.)

(With Plate II and 12 Text-figures.)

CON'TENTS.

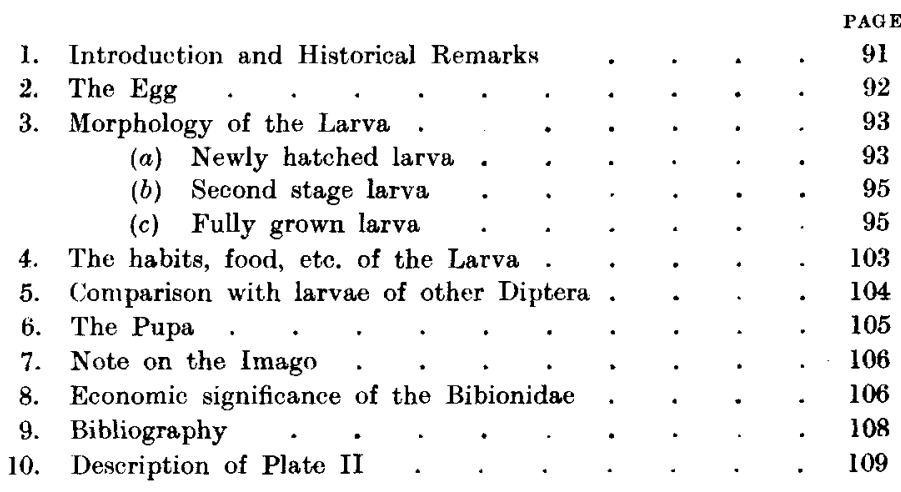

\section{INTRODUCTION AND HISTORICAL REMARKS.}

During the early part of 1917 I found in the soil of a permanent pasture field at Holmes Chapel, Cheshire, a number of what appeared to be Dipterous larvae of the family Bibionidae, and Dr A. D. Imms suggested to me that a study of these larvae would form a very interesting piece of work.

Some of these larvae were reared and on emergence the fly proved to be Bibio Johannis L., for the confirmation of the identity of which I have to thank Mr H. Bury. To Dr Imms I desire to express my thanks for his assistance in many ways during the whole course of the investigation. The work has been carried out in the Department of Agricultural Entomology, Manchester University. 


\section{Larval and Pupal Stages of Bibio Johannis $L$.}

Hitherto there has been no complete account of any Bibionid larva, but only partial descriptions and fragmentary accounts of the lifehistory.

On account of the frequent occurrence of larvae of this family, and their possible economic importance in certain cases, I have been led to investigate the present species as fully as possible.

The earliest description of the larva and pupa of any species of Bibio met with, is that given by Reaumur (1741). Reaumur describes and gives figures of the larva and pupa of the "St. Mark's Fly" (Bibio Marci), but, as with all other figures of larvae and pupae of this genus seen, the figures are not sufficiently clear for purposes of identification of species. De Geer (1776) gave the first account and figures of Bibio Johannis and in 1832 Lyonet gave a description of Bibio Marci. Bouché in 1834 described and figured the larva and pupa of Bibio hortulanus, and also figured the mouth parts of the larva, but these figures again are very indefinite. Westwood in 1840 referred briefly to the larva of this genus and gave a small figure. In 1872 Beling described the larvae and pupae of a number of species of Bibio and Dilophus, amongst others those of Bibio Johannis. Needham in 1902 gave an account of the occurrence of swarms of the larvae of Bibio fraternus, with descriptions and figures of the larva and pupa, while Sharp(23) has figured a larva of an unnamed species of $B i b i o$, and has also given a figure of a portion of the integument of the larva.

In addition to these accounts there are several records of the finding of larvae of different species of Bibio in great numbers in a small area (13) and references to damage done by them to cultivated plants. The larvae of the different species of Bibio appear to be very similar, which makes identification of the larvae difficult.

\section{THE EGG.}

The egg (Text-fig. 8, p. 112) is $\cdot 63$ to $\cdot 66 \mathrm{~mm}$. long and $\cdot 13$ to $\cdot 15 \mathrm{~mm}$. broad. It is cylindrical with rounded extremities, and is approximately straight. The eggs are not shiny but have rather an opalescent appearance owing to their being covered with small pointed projections. They are at first of a uniform light straw colour but after a few days a darker patch appears at each end. 


\section{MORPHOLOGY OF THE LARVA.}

\section{(a) Newly hatched LARVA.}

The eggs hatched under laboratory conditions in forty-eight days, on May 30th, which appears to be an exceptionally long period. The newly hatched larva is from 1.3 to $1.5 \mathrm{~mm}$. in total length, of which the head measures about $\cdot 18 \mathrm{~mm}$., with a breadth of $\cdot 16$ to $\cdot 19 \mathrm{~mm}$. The head is relatively large, yellow brown in colour, and bears a number of long setae.

The body is almost colourless, the contents of the alimentary canal showing through as a broad dark line. In shape it is cylindrical, but it is slightly curved, as in the adult. The body is divided into twelve segments, of which the first is the largest. Each segment bears a number of long slender setae, the length of which varies on different parts of the segment.

Between the long setae on each segment are a number of smaller projections on the cuticle, which correspond to the scale-like structures of older larvae. These projections each consist of a blunt conical base, bearing a single pointed seta, which is directed obliquely backwards. Of the long setae those on the sides are the longest, except on the last and penultimate segments, on which segments those setae situated dorsally are the longest. Each of the long setae arises from a base similar to, but larger than, those of the small setae (Text-fig. 11, p. 112).

The young larva bears a single pair of spiracles, which are situated on the last segment in a corresponding position to that occupied by the spiracles of this segment in the fully grown larva. At the present stage each spiracle has only a single opening.

The structure of the spiracles is similar to that of the spiracles on segments three to ten of the adult larva, but they project very little from the body.

From the extremity of the last segment the larva is able to protrude a pair of membranous conical structures, one on either side of the anus. These structures are protruded by blood pressure, and withdrawn by means of special muscles attached to them. They assist the larva in its movements in a similar manner to the pseudopodia of other larvae.

The head at this stage is very similar to that of the full-grown larva. The antennae, maxillae and labrum show very slight differences from the adult form. The mandibles are shorter at this stage, and their teeth are relatively longer. The groups of setae on the mandibles are present, 


\section{Larval and Pupal Stages of Bibio Johannis $L$.}

but they are not so well developed as in the full-grown larva, the setae being shorter and fewer in number.

In the labium, the submentum is rather less stout than that of the full-grown larva, the anterior projections are longer and sharper, while between them is a third projection.

Alimentary Canal. The alimentary canal of the young larva is similar to that of the adult larva. The caeca are rather wider in proportion to their length, and are filled with a yellow fluid. The peritrophic membrane is present as a straight delicate tube lying inside the mesenteron, and extending from its anterior end to about the point at which the posterior caecum opens into the digestive system. The Malpighian tubes are similar to those of the fully grown larva, entering the alimentary canal by a common duct, but the tubes are not enlarged at their point of union. They are colourless, but contain numerous light yellow granules.

Tracheal System. From each spiracle of the pair on the last segment a single short trunk passes inwards, dividing into two on entering the body. One of these branches passes forwards laterally, giving off a fine transverse branch in each segment which connects with the main lateral trunk of the other side; in each segment, except the second and eleventh, a short branch is given off which passes outwards to the cuticle, but has no opening to the outside (Text-fig. 12, p. 114).

From the transverse connective in the first segment, and from the main lateral trunks, a number of branches enter the head and are distributed there.

From the lateral trunks in the eleventh and twelfth segments and from the transverse connective in the twelfth segment a number of fine branches are given off which pass to the heart.

The second of the two branches (into which the trunk from the spiracle divides on entering the body) again divides into a number of finer branches. Most of these branches are distributed in the twelfth segment, but one branch passes forwards, and divides into two at the end of the eleventh segment. The finer of these branches passes to the loop in the alimentary canal, while the other passes forwards into the head outside the main longitudinal trunk. This lateral trunk connects with the branch which passes outwards from the main trunk in each segment, except the second and eleventh.

Circulatory System. The heart lies in segment eleven and in the anterior part of segment twelve; it is continued forward as a dorsal vessel of slightly narrower calibre, to the anterior end of the body. 
The heart has a small posterior chamber, provided with a pair of lateral openings by means of which the blood enters. These openings are closed by means of valves when the heart contracts, thus forcing the blood along the dorsal vessel. The latter is very thin walled, the nuclei of the cells of which it is composed bulging inwards into the vessel. The blood is a colourless fluid containing relatively large colourless corpuscles which are usually oval in shape.

Nerrous System. The nervous system is similar to that of the fullgrown larva. The supraoesophageal ganglion lies in the front of the first segment with the suboesophageal ganglion beneath it. The first thoracic garglion lies in the posterior region of the first segment, the second is similarly situated in the second segment, while the third ganglion lies rather more forward in the third segment. The eight abdominal ganglia lie in the posterior half of their segments, except the eighth, which is in the front of the eleventh segment.

\section{(b) Second stage larva.}

The larvae passed into the second stage after nineteen days, under laboratory conditions.

This larva is much more like the full-grown larva in external appearance than is the newly hatched form.

The head does not appear relatively so large, while the long setae on the body have disappeared, the body now bearing processes similar to those of the fully grown larva. The cuticle also bears scale-like structures similar to those of the full-grown larva, but somewhat smaller. The spiracles on the last segment are larger but each has still only a single opening. A smaller pair of spiracles is situated on the first segment as in the full-grown larva, and there is also a still smaller pair of spiracles on the tenth segment. From this latter pair of spiracles the outwardly directed branches from the main longitudinal trunks in that segment take their origin. The tracheal system is similar to that of the first stage larva, but it has more numerous branches.

The mouthparts are very little different from those of the first stage larva, but are slightly more like those of the full-grown larva.

\section{(c) Fully grown larva.}

(a) External Form. The larva is 10 to $11 \mathrm{~mm}$. long by 1.2 to $1.3 \mathrm{~mm}$. wide and its thickness is a little less than its width. Of this length about $.9 \mathrm{~mm}$. is the length of the head, which is of slightly less 


\section{Larval and Pupal Stages of Bibio Johannis $L$.}

width than length. The larva is clearly divided into two distinct regions, (i) The Head and (ii) The Body.

The Head is very clearly defined and is invested by a shining chestnutbrown chitinous capsule which is darker and stronger than the covering of the body. The head can be slightly retracted, so that the posterior end is covered by the front of the first segment of the body. It is darker in the anterior half and on that half bears a few long single setae, while the posterior half, which is lighter, is bare. From the centre of the hind edge of the head arises a fine dark line which passes forwards and almost immediately divides into two, which curve outwards to the bases of the mandibles (Plate II, fig. 5).

The paired appendages of the head are the antennae, mandibles and the first maxillae. Between and below the maxillae there lies a rather peculiar shaped plate. This structure probably represents the second maxillae fused to form a single organ. This plate has another rather crescent shaped plate lying above it. A similar structure often occurs in Dipterous larvae. The lower plate is regarded by Miall and Hammond (17) as the sub-mentum, while the upper plate is regarded as the mentum, which, they consider, has gradually slipped behind the submentum.

The sub-mentum is dark and strongly chitinised, with a central lighter area bearing a group of short setae (Text-fig. 7, p. 112).

There does not appear to be any indication of eyes, and the antennae (Text-fig. 6, p. 112) are small and inconspicuous. The mandibles (Text-fig. 4, p. 111) are large, strong and dark, and have each two large teeth and two smaller ones. They bear on their inner side a prominent group of fine setae some of which are slightly branched.

The maxillae (Text-fig. 5, p. 111) are stout and have a distinct palp. The tops of both palp and maxilla bear a number of setae.

The Body is nearly cylindrical, but is slightly flattened dorso-ventrally and normally is curved slightly, the ventral surface forming the inside of the curve. The body consists of twelve segments, of which the first is the longest and has rather the appearance of two segments, but the imaginal discs prove it to be a single segment.

The body bears ten pairs of spiracles which are brown in colour and are situated, a pair on each segment, on all segments except the second and eleventh. The spiracles are situated laterally except those on the twelfth segment which are placed more dorsally than the others. The spiracle on the first segment (Text-fig. 1, p. 110) is about twice the size of those on the third to tenth segments, and that on the twelfth segment 
is about four times the size of those on the third to tenth segments (Text-figs. 2 and 3, p. 110).

The first segment (Plate II, fig. 1) is divided dorsally into two slightly raised areas, of approximately equal size, by a transverse groove. On the first of these areas are six processes, arranged in a transverse row, those towards the sides being about twice as long as those in the centre. The ventral side is similarly divided into three areas, of which the second is below the first dorsal area, but is curved back in front, and a smaller, roughly triangular, area is formed in front of it, on which are two short processes. On the second area are two short processes in the centre, one about four times as long on each side, and one on each side of intermediate length between those at the sides and those in the middle. On the third raised area are six processes of which the longest, at the sides, are as long as the intermediate ones on the second area. The spiracle on this segment is situated laterally and slightly farther back than the second row of spines on the dorsal side, and projects from the side a distance equal to its own diameter.

The second segment is divided dorsally into three areas in the same manner as the first segment. Of these areas the first bears a process on each side, and the second a row of six processes. Ventrally the same division is visible, the first area bearing two central processes, and the second a row of six processes.

The third segment is similar to the second, but bears a pair of spiracles laterally on the front part of the first raised area.

The fourth segment is also divided into three areas, and bears on the front of each side of the first raised area a spiracle, and on the middle area a transverse row of six processes. Ventrally, it has a row of six processes on the first area, and another row of six processes on the second; the two lateral processes of the latter row appearing behind and a little below the spiracle.

The fifth to tenth segments are similar to the fourth.

On the eleventh segment the row of six dorsal processes are much enlarged; of these, the middle pair are the largest and the lateral ones one-third the size. About the middle of the ventral side of this segment is a row of six processes similar to those on the preceding segments. There is also a lateral process on each side half-way between the dorsal processes and the front edge of the segment (Plate II, fig. 4).

The four processes on the dorsal side of the twelfth segment are also much enlarged, and are situated on the hind margin of the segment. There is, furthermore, a short process on the middle of the side of the 
ventral surface. The spiracles of the twelfth segment are situated halfway between the lateral processes of the dorsal row, and the front of the segment, and they project twice as much as the preceding spiracles (Plate II, fig. 4). These spiracles have each two openings, while the other spiracles have only one.

The body is covered by a tough cuticle which is actually of a light brown colour, but the larva appears darker owing to particles of soil adhering to it, and to the dark contents of the alimentary canal. The cuticle bears small irregular shaped scale-like structures, which do not touch one another. These structures are of various sizes, and the larger ones are rather conical and bear from one to eight short and usually backwardly directed spines (Plate II, figs. 7 and 8 ). On the bases of the processes, and on the spiracles of the larva, these structures are closer together and give a more scale-like appearance, while on the processes the spines become considerably longer than elsewhere.

Each intersegmental region bears a row of depressions which vary considerably in shape. They are placed side by side (Plate II, fig. 6) and apparently similar structures are situated, often singly, on other parts of the segments. These depressions are of a darker colour than other parts of the cuticle, and are surrounded by elongated spineless scale-like structures.

On the twelfth segment the scale-like structures form a closer covering, which has rather the appearance of a squamous epithelium. The spines of the scale-like structures on the dorsal surface of this segment are very much reduced or absent, except on the processes, while on the ventral surface a single stouter spine is present on each scale.

From the end of the twelfth segment the larva can protrude pseudopodium-like structures similar to those of the newly hatched larva, but at this stage they are relatively smaller.

(b) Internal structure. The Integument consists of a chitinous cuticle, with the hypodermis or chitogenous layer underlying it.

The Cuticle consists of two layers, of which the outer is considerably the thinner, is of a light yellow colour in sections, and is highly refractive, except in the head, where the outer layer is of greater thickness than elsewhere, and is of a brownish yellow colour in sections. The inner layer, which is relatively thick, appears to be only partially chitinised and is more readily stainable than the outer.

The Hypodermis appears to be an undifferentiated stratum of protoplasm containing scattered oval nuclei which are hard to distinguish, no cell wall being distinguishable. Below the hypodermis and in contact 
with its inner surface, is a layer of flattened, irregular-sized cells. Miall and Hammond (17) consider that these are the "Wandering cells." In this larva this sub-hypodermal layer of cells appesis to be continuous. The scales consist of a thin stratum of the outer layer of cuticle, which is not continuous beneath them, the interior of the scale being occupied by cuticle of the inner layer. The hypodermis does not enter the scales although it bulges outwards slightly towards their bases. The processes are of similar structure, the hypodermis bulging upwards barely to the base.

\section{The Digestive System.}

The alimentary canal takes a nearly straight course through the body from the front of the head to the end of the last segment, but it is slightly longer than the body. It is divided into Fore-Gut, Mesenteron or Mid-Gut, and Hind-Gut, and is provided with salivary glands, caeca and Malpighian tubes (Text-fig. 9, p. 113).

The Fore-Gut extends from the mouth to the end of the first segment of the body.

The mouth is formed by the labrum above, the mandibles at the sides and the labium and maxillae below. The inner surface of the labrum (the epipharynx) bears numerous short setae, the arrangement of which is shown in Text-fig. 6, p. 112. Some of these setae are probsbly sensory while others may assist in holding and cutting the food.

The mandibles are mostly used in taking the food into the mouth, and are moved in the same, or almost the same plane, but their shape causes the food between them to be worked against the epipharynx, which bulges slightly downwards. Just behind the mouth the fore-gut dilates slightly into the pharynx, from the walls of which muscles radiate to the walls of the head, and circular muscle fibres are present in its walls.

The Oesophagus (Text-fig. 9) is a straight and narrow tube of simple structure. It is lined by a chitinous intima, which is considerably folded. Outside the intima, is an epithelium in which the nuclei can be seen but not the cell walls. Outside the epithelium lies a muscular coat, consisting of a layer of circular fibres, forming a series of transverse rings. On the outside of the muscular coat is a thin membrane of connective tissue. Towards the middle of the first segment of the body the oesophagus dilates slightly, and the intima here becomes stronger and has the appearance of small groups of teeth. Behind this is a short region or Gizzard with very strongly developed circular muscles and of 


\section{Larval and Pupal Stages of Bibio Johannis $L$.}

smaller diameter (Text-fig. 9). The oesophagus ultimately joins the cardia or first portion of the mesenteron, at the end of the first segment.

The Salivary Glands. The salivary glands are rather small, and lie one on either side of the alimentary canal, towards the end of the first segment. Each gland is hollow and has a lining of protoplasm. Strands of protoplasm also stretch across the interior of the gland forming a complicated network in which, as well as in the lining of the gland, are large nuclei. The salivary duct passes forwards ventrally from the anterior end of each gland.

The oesophagus is continued a short distance into the cardia, and is then sharply turned back and passes upwards again to the point where the epithelium of the cardia begins, forming an oesophageal valve. The part of the oesophagus forming the valve is very similar in structure to that of other parts as far as the first bend. It consists of intima, epithelium, and well-developed circular muscle fibres. The part of the oesophagus between the two bends is composed of an epithelium of much larger cells than the other part, without the muscle fibres. The space between these two parts forms a blood sinus, and is crossed by bands of connective tissue fibres, and there are also bands of longitudinal muscle fibres between the two portions of the oesophagus.

The part of the cardia which follows the oesophagus, and surrounds the valve, consists of deeply staining columnar cells, followed by less deeply staining cells, and this tissue makes several folds into the cardia. These folds chiefly involve the epithelium, but also the moderately developed coat of circular muscle fibres to a small extent. From the anterior part of the cardia a number of bands of muscle fibres stretch to the walls of the oesophagus, without resting on the alimentary canal throughout their length.

From the cardia the three large caeca take origin; the longest, which lies parallel to the mesenteron and ventral to it, is about $2.5 \mathrm{~mm}$. long. The other two, which are of about equal length ( 1.3 to $1.4 \mathrm{~mm}$.), open laterally from the cardia and are slightly inclined upwards.

The caeca are composed of an epithelium similar to that of the mesenteron, the cells of which are rather larger and project slightly into the lumen. Outside the epithelium is a membrane of connective tissue, but no muscle fibres. The caeca are filled with a finely granular substance.

The Stomach which follows the cardia has walls of the following structure, from within outwards: 
1. The peritrophic membrane, which forms a thin-walled tube lying loose within the stomach from the cardia to near the end of the stomach.

2. The epithelial layer is composed of cells with rather large and dark-staining nuclei, and in some parts a distinct "striated margin" was seen.

3. The basement membrane, outside which is-

4. The muscular coat consisting of poorly developed bands of circular and longitudinal muscle fibres.

5. The connective tissue, which lies outside the muscular coat.

The thickness of the epithelium varies slightly in different parts of the stomach, and it gives off protrusions into the cavity which are finely granular, and feebly staining.

From near the posterior end of the stomach a fourth caecum opens on the ventral side. This caecum is smaller than the others and lies parallel to the stomach with its closed end forwards. Its walls are of a similar structure to those of the other caeca, but are considerably folded near the attached end. The cells of all four caeca show a wellmarked "striated margin."

The Hind-Gut commences in the ninth segment, but its length is considerably increased by the formation of a loop. It is divided into three parts, the ileum, colon and rectum (Text-fig. 9).

The Ileum commences as a slight dilation, and is lined with a layer of epithelium composed of rather large cells, slightly rounded on the inside, and bounded by a fine intima. The epithelium rests on a basement membrane, outside which is a strongly developed coat of circular muscle fibres outside which again are longitudinal muscle fibres, the whole being covered by a thin connective tissue membrane. The circular muscles are very close together, each band touching those next to it. At the commencement of the ileum the circular muscles are particularly well developed.

The Malpighian tubes are four in number, and at their attached end they are dilated for a short distance to about twice the diameter of the remainder of their length.

The four dilated ends join together and join the anterior end of the ileum by a short common duct, which lies on the left of the alimentary canal.

The tubes are covered on the outside with a delicate membrane, inside which is a lining of protoplasm containing numerous large nuclei which bulge into the cavity of the tube. The nuclei of the dilated part 


\section{Lareal and Pupal Stages of Bibio Johannis $L$.}

are smaller than the others but more numerous. The protoplasm contains many fine granules.

The Colon, which follows the ileum, is of rather larger diameter, and is less muscular than the ileum. It has a fine intima, outside which is a layer of epithelium rather thinner than that of the ileum. The colon is invested with circular muscle fibres similar to those of the ileum, but they are neither so large nor so close together. Externally the colon is covered with a delicate connective tissue membrane.

The Rectum is of considerably smaller diameter than the colon. Its epithelium and intima are deeply folded, filling up much of the gut. The muscular coat is well developed and composed of circular muscles, with a connective tissue membrane outside them.

The Nervous System. The nervous system of the Bibio Johannis larva consists of a brain or supraoesophageal ganglion, a suboesophageal, three thoracic and eight abdominal ganglia. The brain is two-lobed and lies in the anterior part of the first segment of the body. The two lobes are distinct but are closely connected.

The suboesophageal ganglion lies directly below the brain, and is connected with it by short but fairly fine oesophageal connectives, which connect its anterior end with the anterior end of the lobes of the brain. The head is almost entirely filled with the muscles of the mouthparts, so that the brain is displaced into the first segment. In this latter region, in larvae near pupation, the rudiments of the adult head may be also found.

The first thoracic ganglion lies just behind the suboesophageal, and is nearly as large, the second is close behind it while the third is farther back. The first ganglion is situated at the posterior end of the first segment, the second lies in the front of the second segment and the third in the front of the third segment.

The abdominal ganglia are smaller, and are situated one in each segment. The first seven ganglia lie in the anterior region of their respective segments. The last abdominal ganglion is considerably larger than the others, and is situated toward the hinder region of the eleventh segment.

In the head is a small frontal ganglion which is connected with the brain.

The connectives between the ganglia are clearly double throughout.

From the ganglia lateral nerves are given off, the distribution of which was not studied. 
The Tracheal System 1.

From each spiracle except those on the last segment a single tracheal trunk passes inwards, and on passing through the integument it divides into three branches. One branch at once divides into a number of fine branches while the other branches connect with the spiracles before and behind, these connectives also giving off fine branches to the tissues.

From each of the openings of the last pair of spiracles a single trunk passes inwards, and each one then divides into two branches.

\section{HABITS, FOOD, ETC.}

The larvae of Bibio Johannis were found near the surface of the soil, amongst the roots of the grasses of the pasture. The soil near the surface was very rich in organic matter in all stages of decomposition, as the field had been pasture for a number of years. The soil was a medium loam on the surface, but becoming heavier a few inches down.

The larvae were usually found at a depth of not more than half an inch below the surface, and some appeared to be actually on the surface of the soil ; they were usually in small colonies, in which the larvae were very close together.

The larvae fed by working particles of soil and organic matter into the mouth by the rather slow movement of the mandibles.

From examinations made of the contents of the alimentary canal it appeared that these larvae had been feeding on decaying vegetable matter only, as only such material and inorganic particles were found.

Several observers record having found the larvae of species of Bibio in cow-dung, horse-dung $(8,15)$ and in other situations where there has been a very high proportion of decaying vegetable matter, as in garden soil (26) and at the base of decaying. tree stumps(19). It appears also that larvae of this genus can feed on the roots of living plants.

The larvae of Bibio Johannis are moderately active and are able to bury themselves in loose soil fairly quickly, assisted probably by their backwardly directed processes.

The larvae and pupae, contrary to the experience of Malloch(15) were not found difficult to rear. They were reared in medium sized glass jars, partially filled with soil, grass, etc., similar to that amongst which the larvae were found, the jars being covered with coarse muslin and the soil kept damp. As it was desired to obtain the fly rather early in the

1 The spiracles have already been described on pp. 96-98. 


\section{Larval and Pupal Stages of Bibio Johannis $L$.}

year, the larvae were kept under cover in a temperature which was always above that outside.

Although the larvae were found during the latter half of an unusually severe winter, they appeared but little affected by the cold and did not descend into the soil to any distance as far as was observed.

No parasites were met with in connection with these larvae, and the only reference to parasites met with in this family, is that of Malloch (15). This observer mentions a hymenopterous parasite of whose connection with this family of hosts he is uncertain. Lyonet mentions finding a "louse" on a Bibionid larva, and a Filaria inside one.

\section{COMPARISON WITH ${ }^{\star}$ LARVAE OF OTHER DIPTERA.}

The structure of the larva of Bibio Johannis indicates that it is very primitive, the larva having twelve complete segments, a comparatively large head that cannot be withdrawn into the first segment, and welldeveloped mouthparts.

The presence of ten pairs of spiracles is very unusual, and is characteristic of the family. The fact that the spiracles of the first and twelfth segments are considerably larger than those of the other segments seems to indicate a tendency for the larva to become amphipneustic instead of peripneustic. Of the mouthparts, the most noteworthy is the labium, which is modified in a similar way to that of Chironomus and Dicranota $(16,17)$. Three caeca is an unusual number, many caeca being found in Chironomus, eight in Anopheles and a few other larvae, four in a number of species, and two in others.

The posterior caecum is also unusual although Dufour found a "caecum latéral" in Tipula lunata, which, however, opened from the intestine and not from the mesenteron as is the case in the Bibio Johannis larva. Four is a common number of Malpighian tubes, but they usually enter the alimentary canal separately.

The oesophageal valve is fairly primitive, considerably more so than that of Simulium or Chironomus (16, 17) or Anopheles (12). It considerably resembles the valve figured by Holmgren(11) in Mycetophila ancyliformans, but is relatively shorter.

The structure of the cardia is also similar to that shown by Holmgren, in having first a regular epithelium of columnar cells, followed by a considerably folded region. In Bibio Johannis however there is a space between the two parts of the oesophagus forming the valve, which contains muscle fibres, and is more like that of Dicranota. 
The peritrophic membrane is very common in Diptera, its length varying considerably. In this larva as in many others the membrane appears to arise from the anterior end of the cardia.

In the general features of its morphology the larva of Bibio Johannis bears a closer resemblance to the larvae of the Mycetophilidae than to any other group. This resemblance appears to be due to the fact that the two families are phylogenetically closely related. The possibility, however, that certain of the characters may be the result of convergence due to similarity of habitat must not be overlooked.

\section{THE PUPA.}

The larvae pupated on March 25th, the pupa being formed in an oval cell of soil, the last larval skin being in the cell with the pupa. The cell was considerably larger than the pupa, and quite smooth, and looked as if it had been formed by the larva pressing outwards in all directions.

The pupa is 7 to $8 \mathrm{~mm}$. long, about $2 \mathrm{~mm}$. broad across the thorax and 1.3 to $1.5 \mathrm{~mm}$. broad across the abdomen.

The cuticle is smooth and white at first, but soon appears darker as the parts of the imago darken and show through owing to the transparency of the cuticle. The abdomen throughout is light in colour, as the abdomen of the imago does not darken completely until after it has emerged.

The pupa of the female is distinctly larger than that of the male particularly in the width of the abdomen.

The head is flat below and is pressed down on to the prothorax. The antenna cases are short and extend little more than half way across the eyes. On the anterior end of the head is a stout process directed forwards, which covers the ocelli of the imago. The cases of the mouthparts are distinct. The thorax is short and thick, and the mesothorax is considerably the largest segment.

The leg-cases lie side by side, touching those of the other side in the median dorsal line, and extend to about the middle of the first abdominal segment. The cases of the first pair of legs are wholly visible, those of the second pair almost so, while only the extremities of the third pair are left in sight. The remainder is covered by the wing-cases, which do not quite meet and extend a little farther back than the leg-cases (Plate II, fig. 3).

Dorsally there is a slight ridge running from the posterior edge of the mesothorax to the process on the head, and along this ridge the cuticle splits for the imago to emerge (Plate II, fig. 2). 


\section{Larval and Pupal Stages of Bibio Johamnis $L$.}

The prothoracic spiracles project slightly in a dorso-lateral position. The boundary between the prothorax and the mesothorax is not marked on the dorsal side, while ventrally the leg-and wing-cases cover almost the whole of the thorax. The abdomen is long, straight and slightly flattened dorso-ventrally and consists of nine segments, the first six of which are about equal. After the sixth segment the abdomen tapers slightly, the last segment having the form of a blunt cone. The last segment bears a pair of stout processes slightly dorsally near its tip, which are nearly as long as the segment.

Apart from these processes and the spiracles, the cuticle of the pupa is bare.

The abdomen bears a pair of spiracles on each segment except the eighth. These spiracles project from slightly before the middle of the sides of the segments.

\section{NOTE ON THE IMAGO.}

The adults emerged from the pupa on April 9th and the following days, but their emergence was probably hastened by the warmer conditions under which they were kept.

The number of individuals of the different sexes, including the pupae which were preserved as well as the adults which emerged, were, males 20 , females 7 , showing a considerable preponderance of males.

\section{ECONOMIC SIGNIFICANCE OF THE BIBIONIDAE.}

There appears to have been a considerable amount of uncertainty as to whether larvae of this family are destructive to the roots of cultivated plants. A number of instances are recorded of such damage by certain species of this family, although Scharov(22) considers them harmless.

Various species are recorded by Theobald (26) as attacking the roots of oats, grass, lettuces, seedling cabbages and young flower plants, while hops appear to be particularly badly attacked, especially by Dilophus febrilis and $D$. vulgaris (20, 27).

Carpenter (4) reports finding larvae of Bibio Marci feeding on potatoes, while Collinge(5) states that Bibio Marci damages tomatoes, young conifers, seedling ash and young spruce. He further adds that Bibio Johannis damages larch seedlings and hop roots, and he considers that these larvae are introduced in manure or leaf-mould. The larvae of Bibio Marci are also recorded by Gillanders(10) as injuring ash seedlings. 
Other records mention Bibio hortulanus larvae as damaging sugar beet(25), spring barley and wheat(18), the damage in the latter instance being so severe that many fields had to be ploughed up and resown.

Curtis (6) states that Dilophus febrilis larvae cause much mischief in gardens. He found them on the decayed portions of planted potatoes and also on the tubers, and in flower pots.

Larvae of Bibio abbreviatus are reported by Strickland(24) to have damaged celery plants. The soft tissue between the fibro-vascular bundles of the stalks was eaten away to a depth of $1.5 \mathrm{~mm}$., and the larvae also burrowed slightly into the stalks. Owing to the large number of larvae the damage was extensive. In this case the larvae are thought to have been brought to the plants in manure.

Some instances of believed damage by the adults of this family are recorded. Lyonet(14) believed that the adults of Bibio Marci damaged the buds of fruit trees, and other writers believed that the adults of this family damage fruit blossom, but it is unlikely that the damage was due to this cause, the flies being more probably beneficial in assisting pollination (31). The adults of Dilophus febrilis are mentioned as being believed to cause damage to hop-cones, but any damage is probably due to their being dried in the cones $(27)$.

Bibio albipennis, which appears to be very common in the United States of America, is considered to be harmless. The larvae are said to feed on dead leaves and stems (7), and they are also mentioned as having been found feeding on oak galls (29), which appears unusual, unless the galls had fallen to the ground.

The larvae of Bibionidae appear to occur very commonly in cow-dung and manure $(8,15)$ and it seems probable that in many instances the larvae have been carried to the plants which they were found damaging in manure. Many of the plants mentioned as being attacked are usually grown with heavy applications of this material.

Theobald(27) states that vaporite and injections of bisulphide of carbon into the soil were found to kill the larvae. He also recommends trapping the larvae by burying old roots in the soil, and then digging them up early in March and destroying the larvae found feeding on them. He also found soot and lime effective in dealing with the larvae.

Carpenter (4) states that the larvae "seemed to be but little affected by the dressings usually applied for killing or repelling underground insects." $\mathrm{He}$ states that various birds, including domestic poultry, devour the larvae readily. Bibio larvae of several species have been found in the food of rooks, starlings and chaffinches (28). 


\section{Larval and Pupal Stages of Bibio Johannis $L$.}

Spraying infected land with a solution of Chili saltpetre in early spring, and harrowing in autumn or early spring after spreading quicklime on the field are recommended (25), while ploughing deeply and rolling at the time of pupation, has also been found satisfactory (18), contact poisons being said to have very little effect.

\section{BIBLIOGRAPHY.}

1. Beling, T. (1872). Zweiflugler-Gattungen Bibio und Dilophus. Verhandlungen zoologisch-botanischen Gesellschaft in Wien, vol. XxII, pp. 617-650.

2. Boucht, P. (1834). Naturgeschichte de Insecten, p. 42, tab. 4, f. 1-10, Berlin.

3. Brandt, ED. (188I). Recherches sur le système nerveux des larves des Insectes Diptères. Comptes Rendus des séances de l'Académie des Sciences, vol. xcIv, p. 983.

4. Carpenter, G. H. (1913). Reports on injurious Insects in Ireland. Econ. Proc. Roy. Dublin Society.

5. Coluinge, W. F. (1913). Seventh Annual Report of Hon. Consulting Biologist. Journ. Land Agents Soc., Oct. (Abstract in Review of Applied Entomology, 1913).

6. CURTis, J. (1860). Farm Insects, p. 467.

7. Davis, G. C. (1894). Bull. No. 116, Mich. Agric. Exp. Station, October, p. 63.

8. DE GaER, C. (1776). Mémoires des Insectes, T. vI, pl. 27.

9. Durour, L. (1835). Recherches Anatomiques et Physiologiques sur les Diptères.

10. Gillanders, A. T. (1908). Forest Entomology, p. 361. William Blackwood and Sons, Edinburgh and London.

11. Holmaren, N. Monographische Bearbeitung einer schalentragenden Mycetophilidenlarve (Mycetophila ancyliformans n. sp.). Zeitschrift f. wissensch. Zoologie, LXxxvir. Bd.

12. Imms, A. D. (1907). On the Larval and Pupal stages of Anopheles maculipennis, Meigen. Journal of Hygiene, vol. vח, No. 2.

13. Lucas, H. (187I). Annales de la Société Entomologique de France. 5 série, tome I, pp. lxvii-lxix.

14. Lyonet, P. (1832). Recherches sur les Insectes (Mém. Posth.), p. 58, pl. 7.

15. Maduoch, J. R. (1917). A Preliminary Classification of Diptera, part. I, pp. 298-300. Bulletin of Illinois Slate Laboratory of Natural History, vol. xu, article iii.

16. Minul, L. C. (1899). Dicranota; a carnivorous Tipulid larva. Trans. Ent. Soc. 1893, part III (Sept.).

17. Mrall, L. C. and Hammond, A. R. (1909). The Structure and Life History of the Harlequin Fly (Chironomus). Oxford; Clarendon Press, 196 pp., I plate and 127 figs.

18. . Molz, E. and Pietsch, W. (1914). Beiträge zur Kenntnis der Biologie der Gartenhaarmücke (Bibio hortulanus) und deren Bekämpfung. Zeits. wissen. Insectenbiol. Berlin, x, 2 and 3, 1914. (Abstracts in Review of Applied Ent. 1914, and in Experimental Station Record, 1915.) 
THE ANNALS OF APPLIED BIOLOGY. VOL. IV, NO. 3

PLATE $\|$
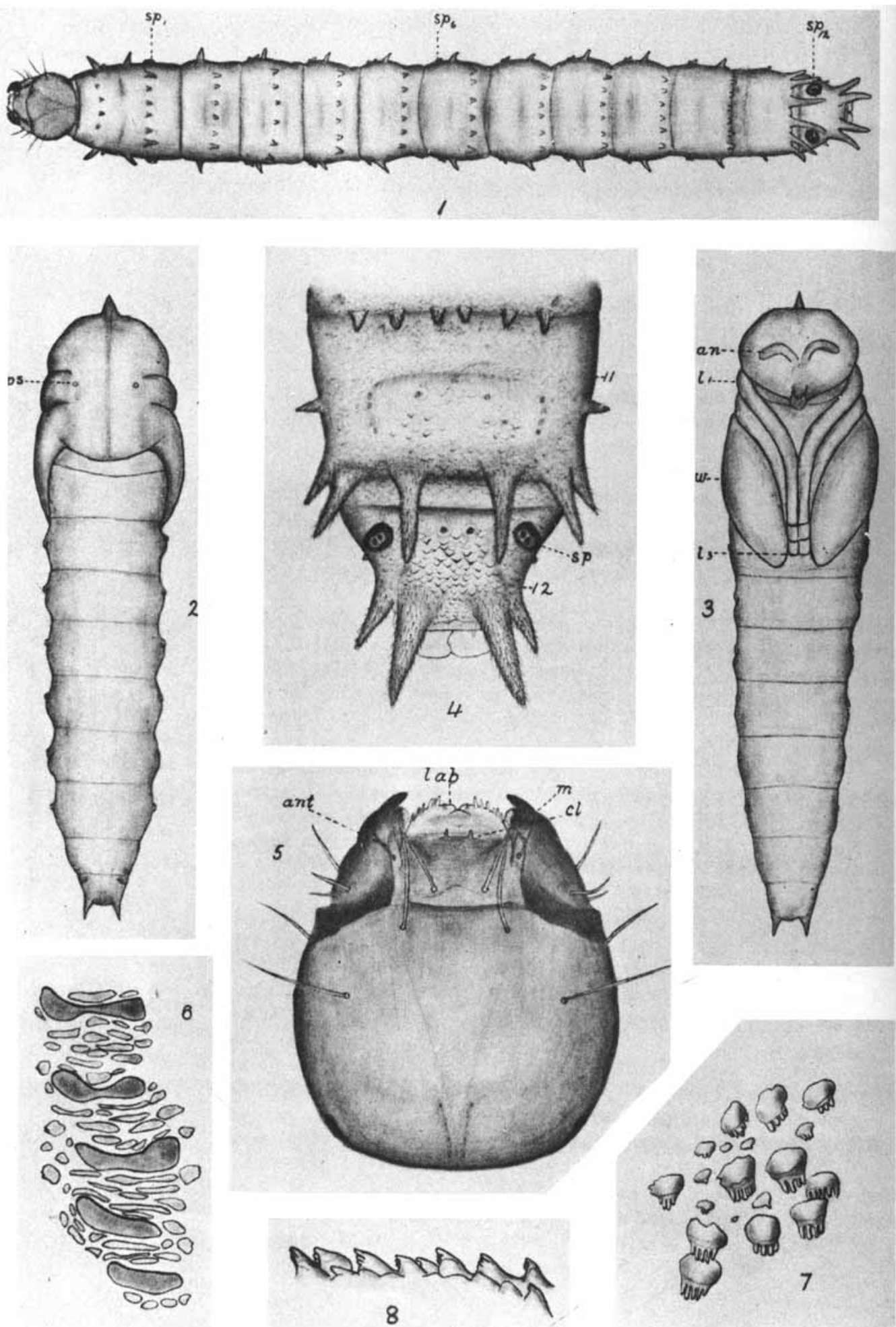
19. Negdham, J. G. (1902). Occurrence of Bibio fraternus. American Naturalist, vol. XXXVI, pp. 181-185.

20. Ormerod, E. A. (1884). Report on Observations of Injurious Insects, p. 56.

21. Reaumur, R. A. F. de (1741). Mémoires des Insectes, tome 5, lère partie, p. 70.

22. Scharov, N. (1915): Injurious Insects in Govt. of Astrachan 1912-1914. Pub. by Entomological Station of Astrachan. (Abstract in Review of Applied Entomology, 1915.)

23. Sharp, D. (1909). Cambridge Natural History, vol. vi, Insects, Part II, pp. $476-477$.

24. Striokland, E. H. (1916). Agric. Gazette of Canada, vol. III, 7, July.

25. Suderkin, G. S. (1913). Pests of Agricultural Plants in Govt. of Voronezh, 1912. Pub. by Zemstvo, Voronezh. (Abstract in Review of Applied Entomology, 1814.)

26. Thwobacd, F. V. (1907-1913). Reports on Economic Zoology.

27. Theobald, F. V. (1909). Journal of the Board of Agriculture, October, p. 567.

28. Throbald, F. V., McGowan, W., and Lergh, H. S. (1916). Reports on the food of the Rook, Starling and Chaffinch. Supp. 15 to Journ. of Board of Agric., May.

29. Walsh, B. D. and Riley, C. V. (1869). Plum-tree Insects. Amer. Ent. vol. I, 11, July, p. 227.

30. Westwoon, J. O. (1840). Introduction to the Modern Classification of Insects, vol. II, p. 528, and fig. 126, 16 .

31. Wuson, H. F. Minor Insect Pests, pp. 195-202, 8 figs. (Abstract in Review of Applied Entomology, 1915).

\section{DESCRIPTION OF PLATE II.}

Fig. 1. Almost fully grown larva of Bibio Johannis, dorsal aspect. sp. spiracle of first segment; sp.s spiracle of sixth segment; $s p_{12}$ spiracle of twelfth segment. $\quad \times 12$.

Fig. 2. Pupa of Bibio Johannis, dorsal aspect. ps. prothoracic spiracle. $\quad \times 12$.

Fig. 3. Pupa of Bibio Johannis, ventral aspect. an. antenna case (right); $l$. leg-case of right leg of first pair; $l .3$ leg.case of right leg of third pair; $w$. wing-case (right). $\quad \times 12$.

Fig. 4. Posterior end of larva, dorssl aspect. 11, eleventh segment; 12. twelfth segment; sp. spiracle of twelfth segment. $\times 30$.

Fig. 5. Head of larva, from above. ant. left antenna; lab. labrum; $m$. right mandible; cl. clypeus. $\times 60$.

Fig. 6. Part of an intersegmental region, surface view. $\quad \times 180$.

Fig. 7. Portion of cuticle, surface view. $\times 180$.

Fig. 8. Ditto, lateral view. $\times 180$. 
110 Larval and Pupal Stages of Bibio Johannis $L$.

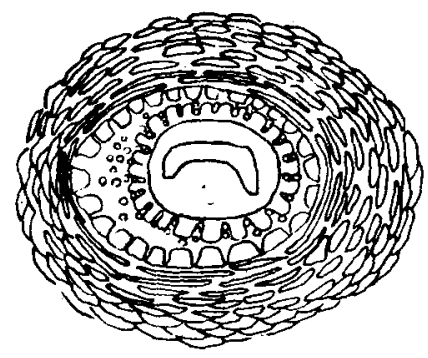

Text-figure 1. Left spiracle of first segment of larva. $\times \mathbf{3 6 0}$.

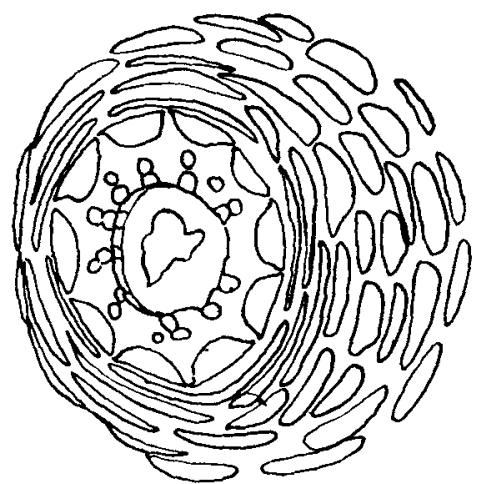

Text-figure 2. Left spiracle of sixth segment of larve. $\times 790$.

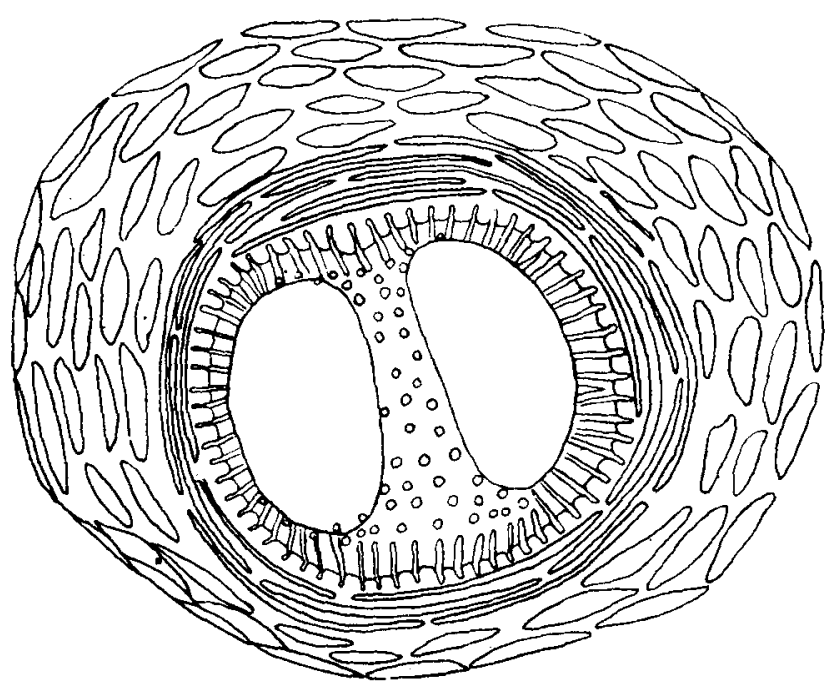

Text-figure 3. Right spiracle of last segment of larva, $\times 360$. 


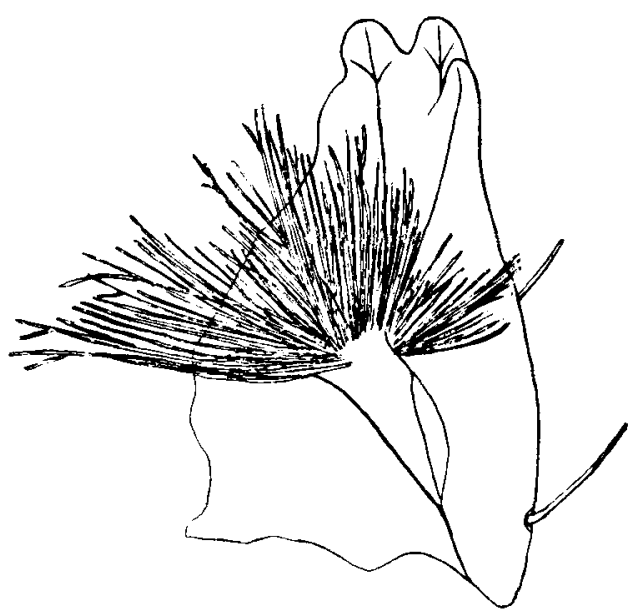

Text-figure 4. Right mandible of larva viewed from the left. $\times 180$

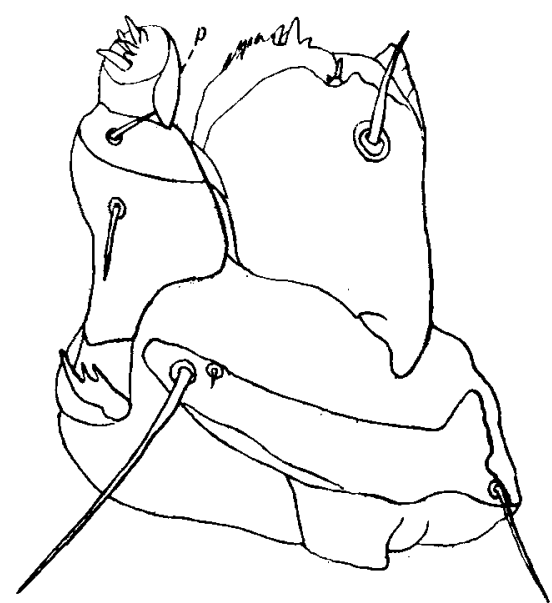

Text-figure 5. Right maxilla of larva from below. $\times 180$. $p$, maxillary palp. 
112 Larval and Pupal Stages of Bibio Johannis $L$.

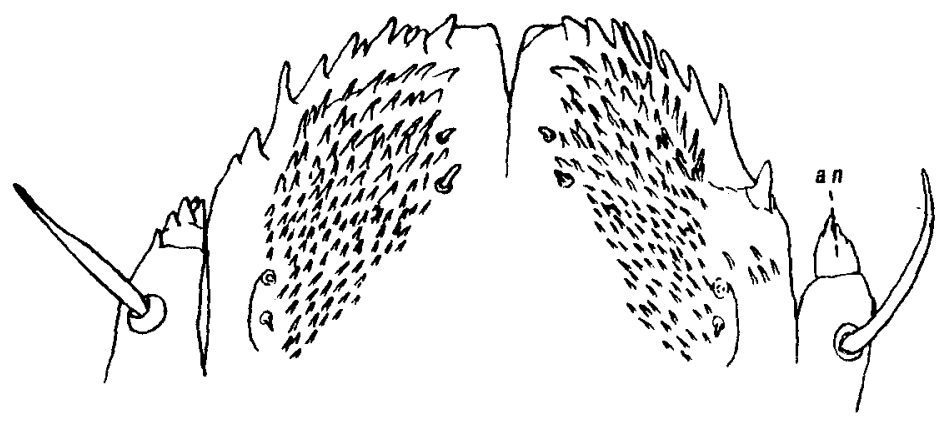

Text-figure 6. Labrum of larva from below. an, antenna. $\times 200$.

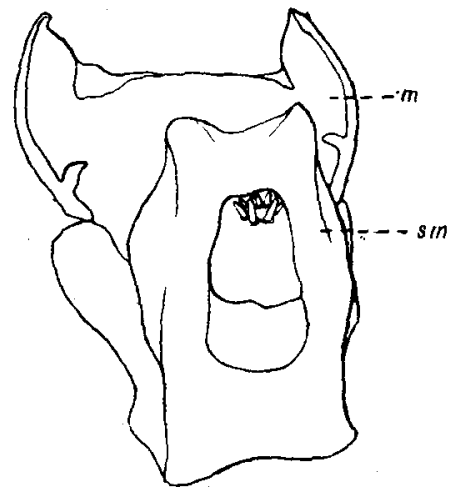

Text-figure 7. Labium of larva from below. $\times 200$. $m$, mentum. sm. sub-mentum.

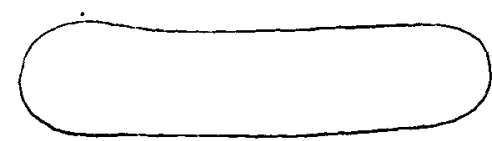

Text-figure 8. Egg of Bibio Johannis. $\times 80$.

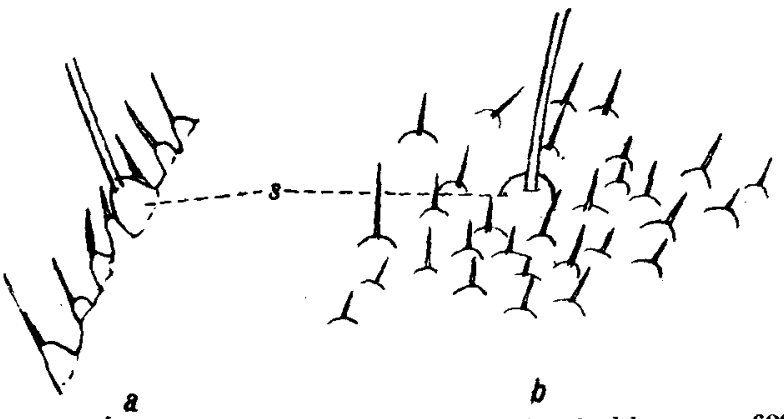
Text-figure il. Processes on cuticle of newly hatched larva.
$a$, Lateral view; $b$, surface view. 8 , base of long seta. 
H. M. MorRIS

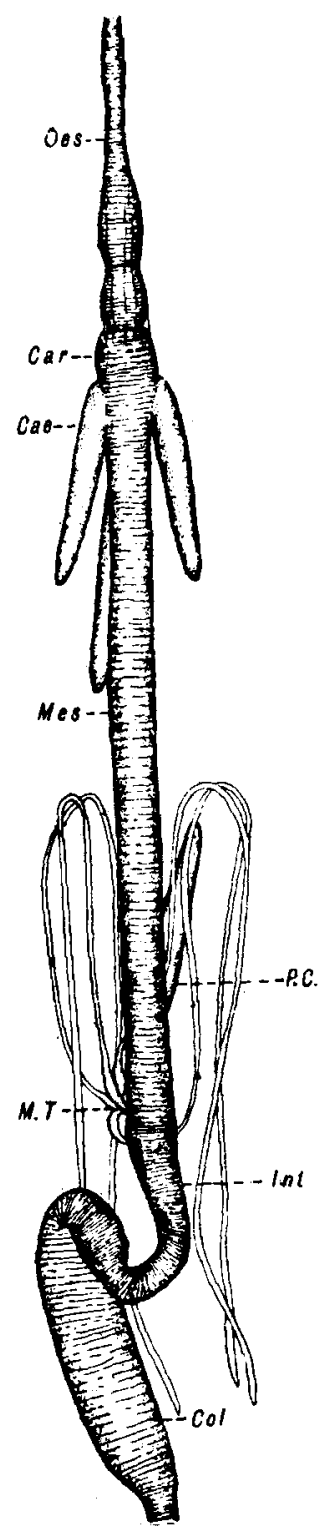

Text-figure 9. Alimentary canal of Bibio Johannis larva. Oes, Oesophagus. Car, Cardia. Cae, Caeca. Mes, Mesenteron. P.C. Posterior caecum. M.T. Malpighian tubules. Int, intestine. Col, Colon.

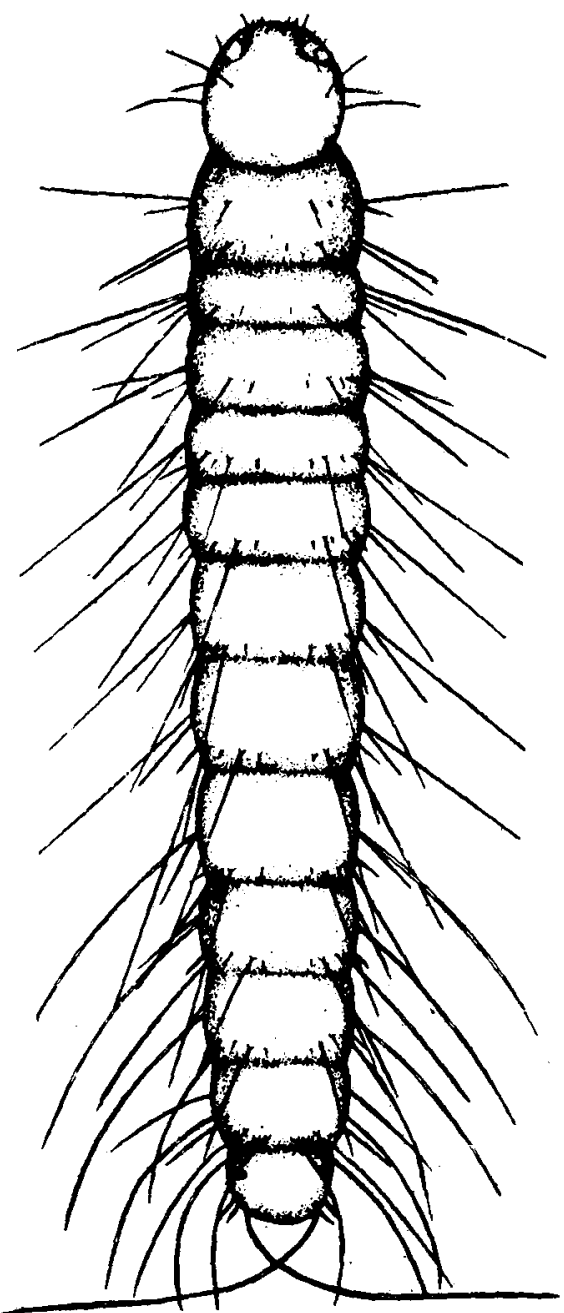

Text-figure 10. Newly hatohed larvs of Bibio Johannis, dorsal aspect. $\times 00$. 
114 Larval and Pupal Stages of Bibio Johannis $L$.

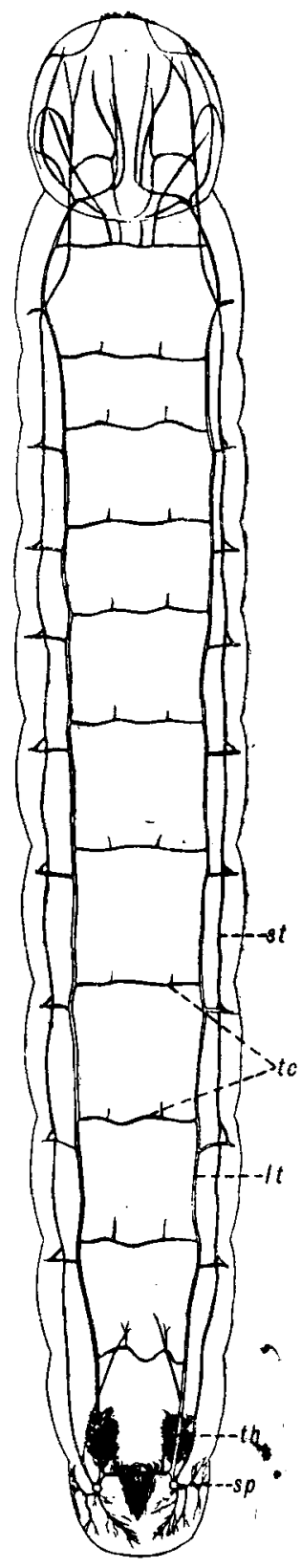

Text-figure 12. Tracheal System of newly hatohed larva. $\quad \times 120$. $u$, Main longitudinal trunk. $s p$, Spiracle. st, Secondary longitudinal trunk. $t c$, Transverse connectives. th, Trachese to the heart. 